\title{
REKONSTRUKSI PENANAMAN NILAI PADA ANAK MELALUI MODIFIKASI DONGENG
}

\author{
Lulu' Sukma Wardani \\ Nurul Hidayah \\ Mohammad Mahpur \\ Fakultas Psikologi \\ Universitas Islam Negeri (UIN)Maulana Malik Ibrahim Malang \\ Jl. Gajayana 50 Malang Telp. 0341-558916
}

\begin{abstract}
Abstrak- Modifikasi dongeng merupakan media paling tepat dalam perkembangan pengasuhan positif anak untuk menanamkan nilai-nilai hidup secara demokratis, tanpa indoktrinasi, tetapi lebih ramah anak. Penelitian ini menggunakan metode kualitatif fenomenologis. Subyek penelitian sejumlah tiga keluarga dengan karakteristik mereka mampu dan memiliki pengalaman menggunakan dongeng sebagai bagian dari teknik pengasuhan anak. Analisis data menggunakan teknik tematik. Hasil penelitian menunjukkan bahwa orang tua memodifikasi dongeng untuk penanaman nilai anak didorong oleh inspirasi kritis masa lalu yang dihayati orang tua dalam pengalaman kepengasuhannya dan membentuk motivasi orang tua dalam mendongeng. Modifikasi dongeng untuk rekonstruksi penanaman nilai yang ditemukan memiliki enam positive parenting, yakni: dialogis, tidak menekan, demokratis, memenuhi hak anak, merangsang ketertarikan anak, dan mendukung aktifitas anak. Adapun rekonstruksi nilai melalui dongeng melahirkan konstruksi baru pengetahuan anak tentang nilai moral-agama, nilai sosial dan realita, dan bahkan mampu meningkatkan ketrampilan dan kreatifitas men dongeng anak.
\end{abstract}

Keywords : modifikasi dongeng, positive parenting dan rekonstruksi penanaman nilai

PSIKOISLAMIKA. Jurnal Psikologi Islam (JPI) copyright (c) 2016 Pusat Penelitan dan Layanan Psikologi. Volume 13 Nomor 2 Tahun 2016

\section{PENDAHULUAN}

Menurut beberapa ahli, penanaman nilai pada anak saat ini, terutama nilai-nilai agama cenderung menggunakan teknik mekanistik-indoktrinasi, dan menempatkan anak sebagai subyek pasif (Mahmud, 2015; Muhtadi, 2007; Raharjo, 2002). Anak diposisikan bukan sebagai subyek moral (Mahmud, 2015) dan tidak ramah. Padahal penanaman nilai dapat dilakukan lebih demokratis dan menyenangkan bagi anak, menggunakan teknik internalisasi yang sejalan dengan penalaran moral anak dan menyatu dengan perkembangan anak (Muhtadi, 2007; Mahmud, 2015).

Penelitian ini menemukan adanya orang tua yang menggunakan penanaman nilai dengan ramah yakni secara dialogis-demokratis, lebih terbuka, interaktif dan anak mampu terlibat secara aktif. Cara ini memberikan kesempatan pada anak untuk mengungkapkan apa yang dipikirkan dan dirasakan sehingga efektif untuk meningkatkan komunikasinya dua arah. Penelitian ini berbeda dengan penelitian tentang metode dongeng lainnya karena penelitian yang lain hanya sebatas mengkaji konten nilai-nilai yang terkandung pada praktik dongeng, belum melihat dari sudut pandang keterlibatan aktif anak tersebut dalam proses menginternalisasi dongeng (Lestari \& Asyanti, 2008; Raharjo, 2002; Sari, 2010; Siswanto, 2014).

Penanaman nilai dengan ramah merupakan bagian dari penerapan pengasuhan positif, dengan memodifikasi dongeng melalui pengubahan konten dan teknik mendongeng. Modifikasi dongeng bertujuan agar penanaman nilai-nilai agama dan moral dapat dipahami anak secara komunikatif, aktif dan menghindari indoktrinasi. Modifikasi dongeng merupakan salah satu variasi untuk mengaktifasi 
fungsi penalaran moral anak (Ahyani, 2010) dengan melibatkan partisipasi bernalar ala anak. Dongeng merupakan media mendorong pemikiran kreatif, menemukan solusi baru bagi permasalahan lampau, menerima kehidupan seseorang, dan membangun harapan untuk masa depan (Biechonski, 2004). Anak juga mengalami fantasi yang krusial sehingga dongeng yang kaya imajinasi sangat tepat diterapkan untuk penanaman nilai pada anak (Nur'aini, 2010; Kartono, 2007; Hedo \& Sudhana, 2014).

Smogorzewska (2012) membuktikan bahwa efektivitas dari penggunaan intervensi yang didasari prinsip dongeng dapat meningkatkan kemampuan bahasa dan berpikir kreatif pada anak. Pada penelitian ini, modifikasi dilakukan dengan menerapkan teknik storyline dan association pyramid yang merupakan teknik dalam memberikan pembelajaran dan samasama menggunakan imajinasi dan visualisasi. Teknik tersebut sesuai dengan perkembangan anak yang cenderung egosentris, centralized, irraversable, kreatif, bebas dan penuh imajinasi (Hidayah, 2009; Kartono, 2007).

Penemuan ini menggugah kesadaran bahwa dongeng secara psikologis tidak semata bernilai artistik, melainkan mampu digunakan sebagai media pengasuhan demokratis. Dengan demikian, dongeng dapat dijadikan sebagai salah satu pilihan terbaik bagi penanaman nilai-nilai positif ditengah dominasi indoktrinasi nilai yang kental dipraktikkan di masyarakat yang kebanyakan searah. Mendongeng menjadi salah satu pilihan kreatif untuk pengasuhan anak sehingga orang tua mempunyai media yang menarik tanpa adanya cara pemaksaan dalam menanamkan nilai (Orde, 2013). Hasil survei pada anak usia 9-19 tahun, anak menyukai dongeng (56\%) karena menarik $(19 \%)$, kisah akhir yang menyenangkan (12\%) dan merasa rileks (10\%) (Orde, 2013). Dongeng dengan begitu menjadi lebih ramah pada anak untuk dijadikan sebagai media penanaman nilai pada anak.

Modifikasi dongeng dapat menjadi media yang ramah karena ada keterlibatan dalam proses merekonstruksi nilai. Sebagaimana sinyalemen Taylor (2012) bahwa dongeng mempunyai sepuluh manfaat yakni,

"Show kids how to handle problems, build emotional resiliency, give a common language (cultural literacy \& canon), cross cultural boundaries, teach story (rising action, climax, and resolution), develop a child's imagination, give parents opportunities to teach critical thinking skills, and teach lessons."
Berpijak pada sudut pandang manfaat dongeng pada anak, modifikasi dongeng merupakan teknik pengasuhan positif. Tekniknya dari pola indoktrinasi yang kurang ramah menuju pola komunikasi demokratis mampu merekonstruksi nilai hidup menjadi kreatif dan aktif. Dengan begitu penanaman nilai anak sejalan dengan kepentingan perkembangan anak, ramah atau lebih otoriter-doktriner, melainkan lebih terbuka (Innayah, 2011; Maulida 2015; Megawangi dalam Muslich, 2011; Mahmud, 2015).

Modifikasi dilakukan menggeser dari dongeng yang bersifat indoktrinasi artistik ke teknik dongeng untuk kepentingan internalisasi nilai yang menempatkan anak sebagai subyek moral. Cara artistik masih menempatkan anak sebagai obyek dongeng searah. Modifikasi dongeng melibatkan praktik menghidupkan penalaran anak tetapi bernuansa artistik sehingga indoktrinasi nilai dapat diminimalisir. Selain itu, modifikasi juga mengubah dari isi dongen fabel ke transformasi dongeng dengan mengolah tema yang lebih kontekstual dari searah menjadi dua arah. Pada akhirnya modifikasi dongeng menjadi ketrampilan pengasuhan positif. Dongeng dengan berbagai pilihan modifikasi menjadi cara tepat bagi orang tua untuk mengubah dari indoktrinasi nilai ke cara demokratis yang ramah karena lebih dialektis, terbuka, dan menyenangkan sehingga transformasi nilai moral sejalan dengan penalaran anak (Mahmud, 2015).

\section{METODE}

Penelitian ini menggunakan metode kualitatif dengan pendekatan fenomenologis karena paling cocok untuk membantu mengungkapkan makna rekonstruksi penanaman nilai dan modifikasi dongeng oleh orang tua. Subyek penelitian melibatkan 3 orang sebagai sumber data tunggal. Kriteria subyek adalah orangtua yang menerapkan dongeng sebagai salah satu ketrampilan pengasuhan dengan isi adanya penanaman nilai pada anak. Teknik pengumpulan data dilakukan pada natural setting (kondisi yang alamiah), sumber data primer dan teknik pengumpulan data lebih banyak pada wawancara mendalam (in depth interview) dan dokumentasi. 

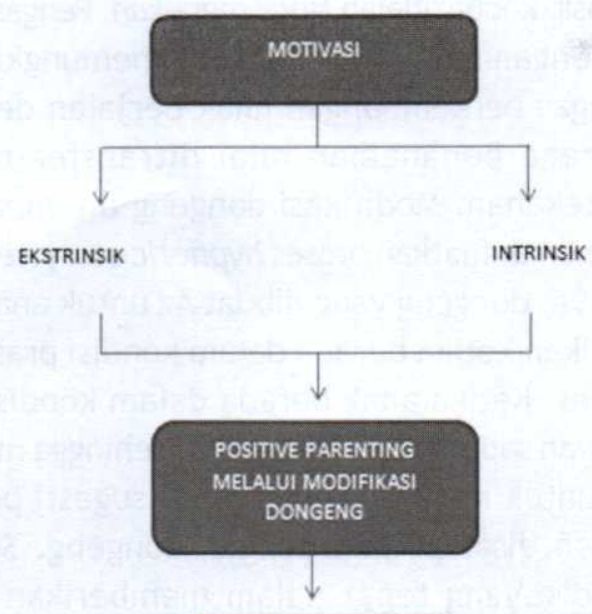

PENANAMAN NILAI

Skema 1 proses penanaman nilai dengan positive parenting dalam bentukmodifkasi dongene

Gambar 1: Skema proses penanaman nilai dengan positif parenting dalam bentuk modifikasi dongeng

Analisis data tematik dilakukan dengan memodifikasi teknik Lyons dan Coyle (2007) menjadi lima tahap yakni a) membaca transkrip secara keseluruhan, b) mengidentifikasi dan memberikan label dari tema-tema, c) menghubungkan beberapa tema dan mengidentifikasi tema besarnya, d) membuat ringkasan kategorisasi dalam tabel, dan e) melakukan interpretasi terhadap keseluruhan kategorisasi kedalam sub-tema menuju teori besar. Tahapan analisis data tersebut telah memenuhi kredibilitas data penelitian sehingga kualitas analisis memenuhi kriteria ilmiah penelitian kualitatif melalui triangulasi data, ahli dan teori.

\section{HASIL}

Motivasi dalam melakukan rekonstruksi penanaman nilai melalui modifikasi dongeng

Penanaman nilai-nilai positif yang dilakukan oleh $\mathrm{Fz}$, Lh, dan Az dengan menggunakan media dongeng pada anak didasari adanya motivasi intrinsik dan ekstrinsik. Motivasi ekstrinsik menggunakan dongeng terinspirasi figur masa lalu orang tua. Lh salah satunya. Dia terinspirasi figur ayah yang telah memberikan dongeng ketika masa kecilnya. Meskipun Lh terbatas waktu bertemu dengan ayahnya, namun melalui dongeng ayahnya, Lh merasa waktu tersebut menjadi istimewa (primetime). Pengalaman tersebut terbawa sampai dia memiliki anak. Dongeng tersebut lalu dipraktikkan dan diwarisakan pada anaknya.
Peristiwa yang sama ada di Az. Dia juga pernah mendapatkan dongeng dari neneknya. Akhirnya dia juga mewarisi dongeng tersebut pada anak-anaknya. Inspirasi Lh dari orang tuanya dan Az dari neneknya, mereka memutuskan menggunakan dongeng sebagai media pengasuhan positif kepada anak secara intensif mengakar dan menumbuhkan motif-motif baru secara intrinsik. Kedua orang tua ini akhirnya secara sadar mengakui memilih dongeng sebagai media pengasuhan yang tepat dalam menanamkan nilai-nilai positif pada anak.

Berbeda dengan sosokAZ. Dia memiliki motivasi ekstrinsik terbentuk atas kekhawatiran dirinya dampak negatif teknologi dan informasi. Dongeng menjadi salah satu penyeimbang untuk menetralisir dampak buruk bagi perkembangan anaknya. Sementara motivasi ekstrinsik mendongeng dari sosok Fz dikarenakan merasa perlunya menambah media pengasuhan setelah menyesal karena ketidakmaksimalan pengasuhan atas peran gandanya dalam keluarga. Hal ini menjadi kesadaran diri Fz sebagai orang tua karena dia tahu anaknya berada dalam masa golden age.

Selain motivasi ekstrinsik, Lh, Az dan Fz mempunyai motivasi instrinsik menggunakan metode dongeng dalam pengasuhan. Motif instrinsik tersebut antara lain mereka mempunyai sudut pandang, pengetahuan dan prinsip bahwa dongeng menjadi sarana tepat membangun kedekatan dengan anak, apalagi untuk menanamkan nilai-nilai positif anak. Motivasi intrinsik berkontribusi sebagai proses sosialisasi nilai orang tua ke anak. Dengan begitu mereka menjadi bersungguh-sungguh dalam membentuk moral dan keilmuan anak secara tepat.

Motivasi ekstrinsik dan intrinsik yang dimiliki oleh ketiganya subjek dalam mendongeng muncul dari proses dinamis. Bagi mereka mendongeng adalah aktivitas yang lahir karena termotivasi dan belajar dari pengalaman di masa lalu. Masa lalu tersebut mampu menginspirasi dan mendorong Lh dan $\mathrm{Az}$ memutuskan dongeng secara prinsipil digunakan menjadimedia yang tepat dalam menanamkan nilai-nilai positif kepada anak. Berbeda dengan FZ menggunakan dongeng sebagai media menanamkan nilai-nilai positif pada anak didasari atas pengalaman dan penyesalan di masa lalunya. Dia telah kehilangan banyak waktu bersama anaknya. Kesadaran tersebut membawa perubahan baru dalam pengasuhan anaknya kini. Dia memanfaatkan dongeng sebagai pelengkap pengasuhan positif, lebih khusus untuk media penanaman nilai pada anaknya.

Dinamika motivasi tersebut mendorong Lh, 
Fz dan Az menerapkan pengasuhan yang positif (positive parenting) kepada anak-anaknya melalui modifikasi dongeng. Modifikasi dongeng yang dikembangkan untuk pengasuhan anak-anak mereka telah membawa pada pola asuh demokratis. Dongeng yang telah dimodifikasi ternyata bersifat terbuka dan tidak hanya bersifat imajiner. Atas dasar itu Lh menggunakan dongeng sebagai media untuk menanamkan nilai-nilai positif. Lh menanamkan nilai-nilai tersebut secara fleksibel, luwes dan tidak memaksakan (otoriter) kepada anaknya.

Modifikasi dongeng yang dilakukan oleh Lh justru memberikan kesempatan terbuka bagi anaknya untuk memaparkan ide-ide atau sudut pandang anak secara pribadi dalam menanggapi dongeng-dongeng yang disampaikan. Selain itu, anak juga diberi kesempatan untuk bertanya dan menyimpulkan nilainilai yang ada didalam dongeng yang disampaikan oleh orang tua. Dongeng yang semula bersifat imajinatif saja, di tangan Lh dikembangkan menjadi komunikasi dua arah yang melibatkan dialog paska mendongeng. Anak dilibatkan sebagai subyek aktif setelah mendengarkan dongeng.

\section{Prinsip positive parenting melalui modifikasi dongeng}

Modifikasi dongeng membawa implikasi ditemukan prinsip positive parenting dalam penanaman nilai pada anak. Prinsip tersebut mencakup dialogis, tidak menekan, demokratis, memenuhi hak anak, dan menstimulasi ketertarikan anak serta mendukung aktivitas anak.

Prinsip dialogis. Proses dialogis dibangun ketika Az, Lh dan Fz memberikan stimulus berupa pertanyaan kepada anak sehingga terjadi sebuah interaksi dialog dengan anak. Dengan demikian, anak diberikan kesempatan untuk mengemukakan apa yang ada dalam pikirannya dan merangsang curiosity pada anak untuk bertanya kembali. Misalnya ketika ada kosa kata baru yang belum dipahami, anak bisa lebih mudah merespon dan bertanya kepada subjek terhadap dongeng yang disampaikan. Otomatis hal ini membuat kosa kata anak menjadi bertambah. Melalui proses ini, anak juga dapat berimajinasi secara kreatif dan bebas karena visualisasi anak aktif ketika membayangkan dongeng yang disampaikan. Anak menjadi lebih aktif karena diminta oleh orang tuanya untuk menentukan alur ceritanya atau menentukan karakter tokohnya. Prinsip dialogis tercapai karena orang tua terambil menstimulasi sudut pandang anak.
Prinsip kedua adalah tidak menekan. Pengasuhan positif dengan modifikasi dongeng memungkinkan tugas-tugas perkembangan anak berjalan dengan baik karena penanaman nilai ditransfer tanpa adanya tekanan. Modifikasi dongeng disampaikan dengan memanfaatkan proses hypnotic-story-telling. Maksudnya, dongeng yang dibuat Az untuk anaknya disampaikan ketika berada dalam kondisi prasadar atau trans. Ketika anak berada dalam kondisi ini, alam bawah sadar anak sedang aktif sehingga mudah bagi Az untuk memasukkan sugesti-sugesti positif yang ingin disampaikan dengan dongeng. Selain itu, kondisi yang tepat dalam memberikan nilai adalah pada saat anak berada dalam konsentrasi penuh, untuk membawa anak dalam kondisi ini $\mathrm{Az}$ memberikan penyampaian dongeng dengan mengemasnya dengan lebih menarik.

Prinsip ketiga adalah penanaman nilai dilakukan secara demokratis. Proses penanaman nilai yang demokratis memanfaatkan sarana diskusi untuk memberikan ruang bagi anak untuk menyetujui secara langsung atau meminta penjelasan kembali mengenai nilai yang disampaikan. Hal ini mendukung adanya nilai-nilai yang diterima tidak lagi disampaikan secara dogmatis, letrerlijk atau kaku, melainkan fleksibel dan kreatif, meskipun itu nilai agama. Selama ini nilai agama diberikan secara dogmatis atau searah kepada anak. Bagi para subyek ditemukan nilai agama yang biasanya bersifat dogmatis disampaikan secara demokratis menggunakan dongeng sehingga transfernya menjadi kreatif. Nilai kreatif tersebut merangsang anak membuat pertimbangan sendiri sehingga anak juga lebih mudah untuk mematuhi apa yang disampaikan.

Prinsip keempat adalah modifikasi dongeng yang memenuhi hak anak. Orangtua memiliki kewajiban mengasuh dan mendidik anak dengan baik tanpa mengesampingkan hak-hak dan kondisi psikologis anak. Lh memegang prinsip ini sehingga anak Lh diberi kesempatan untuk memutuskan (decision making) atas apa yang akan dilakukannya. Kebebasan diberikan kepada anak dari Lh, namun dengan batasanbatasan tertentu sehingga tidak liberal. Oleh karena itu hak-hak anak dapat terpenuhi dan kewajiban subjek sebagai orangtua pun dapat terpenuhi. Di sisi lain anak juga diberikan kesempatan untuk mengembangkan kemampuan dan kreativitasnya melalui dongeng motivasi versi $\mathrm{Az}$

Prinsip kelima adalah merangsang ketertarikan kepada anak. Pendongeng mengambil plot dongeng secara dinamis ketika bercerita. Setiap alur yang akan diceritakan dibuat penasaran agar anak 
selalu tertarik mengetahui kelanjutannya. Daya tarik tersebut memang didukung oleh ketrampilan pendongeng (orang tua) dalam mengemas cerita lebih menarik. Anak menjadi tertarik (interested) terhadap setiap sesi cerita. Anak pun beratensi tinggi terutama ketika alur cerita mencapai klimaks. Dampak ketertarikan anak tersebut menjadikan dongeng yang dikembangkan oleh $\mathrm{Az}$, Lh dan Fz mampu merangsang minat baca anak, terutama sumber bacaan yang berisi dongeng. Langkahnya dimulai dari melihat gambar yang ada dalam buku dongeng. Anak mulai bangkit daya tariknya dan curiosity sehingga anak terdorong menanyakan maksud gambar tersebut. Az juga menjelaskan gambar yang memiliki kesesuaian dengan tulisan cerita di buku. Proses berulang-ulang yang lambat laun akhirnya anak semakin mengerti dan mampu menghafal tulisan. Proses literasi ini yang mendorong anak tertarik dan memiliki minat membaca buku.

Perhatian anak yang intensif tersebut yang membantu anak bisa mengingat cerita di dongeng. Bahkan, Fz memanfaatkan cara ini untuk menghafal ayat dalam Al-Qur'an. Teknik menghafal menjadi lebih mudah karena ada rehearseal (pengulangan) dalam setiap ayat yang dibacakan di dalam sebuah cerita. Namun Desmita (2009) mengungkapkan bahwa teknik pengulangan ini bukan merupakan strategi khusus yang efektif untuk memori jangka panjang, kecuali ditambahkan melalui proses organization (pengkategorisasian), imagery (perbandingan), dan retrieval (pemanggilan kembali).

Modifikasi dalam dongeng memungkinkan informasi sampai pada memori jangka panjang anak karena ada proses rehearsal (pengulangan) ketika ayat dibacakan, organization (pengkategorisasian) ayat tertentu, bersamaan dengan cerita dongeng, imagery (perbandingan) yang memungkinkan anak untuk mengimajinasikannya secara bebas. Kemudian dilakukan retrieval (pemanggilan kembali) di akhir cerita serta di waktu yang lain hanya pada ayatayat tersebut.

Prinsip yang keenam yaitu mendukung aktivitas anak (supportif). Ketika anak sudah tertarik dengan dongeng maka orang tua memberi dukungan yang nyata dengan memberi buku dongeng. Pemberian buku ini sejalan dengan kesempatan anak tertarik pada cerita dongeng sehingga nilai-nilai yang ditransfer mendapatkan momentum atensi dan daya tarik anak. Ketiga orang tua tersebut juga melatih keterampilan anak mendongeng. Oleh karena itu para orang tua tersebut belajar terlebih dahulu bagaimana cara melatihkan dongeng dengan baik pada anak. Setelah menguasai keterampilan mendongeng, maka disampaikanlah kepada anak cara mendongeng. Selain itu orang tua menyertai penerapan nilai-nilai melalui keteladanan kepada anak.

LH telah mengembangkan media dongeng secara demokratis dan memunculkan formula baru penanaman nilai. Menurut LH, media dongeng memiliki kontribusi yang besar dalam menerapkan nilai-nilai tertentu seperti pengetahuan tentang nilai moral, agama, keterampilan maupun kreativitas. Kesemuanya menjadi satu kesatuan yang dapat ditransformasikan kepada anak secara langsung, dialogis, kreatif, dan supportif.

Bentuk rekonstruksi nilai melalui modifikasi dongeng

Secara aplikatif penanaman nilai-nilai positif yang diberikan oleh orang tua tercermin dari beberapa temuan. Nilai tersebut merupakan jalinan dengan cerita baik karena ceritanya bermuatan nilai-nilai dan proses dialektika yang terjadi antara orang tua dengan anak. Ada lima dinamika rekonstruksi nilai dan kandungan internalisasi dalam penggunaan metode dongeng yakni pengetahuaan anak, nilai moral anak, nilai agama anak, nilai sosial dan realitas, dan ketrampilan dan kreatifitas. Penjelasan kelimanya terangkum sebagai berikut.

Pengetahuan. Pengetahuan tentang dongeng disampaikan oleh Lh sebagai transformasi keilmuan yang dimiliki Lh ke anaknya. Pengetahuan yang dimaksud adalah pengetahuan umum, agama, moral dan lingkungan sosial anak. Melalui dongeng orangtua ada ruang mengajak anak untuk memahami nilainilai hidup. Dongeng menjadi ruang relasi orang tua anak membangkitkan (menstimulasi) imajinasi anak mengenai nilai-nilai hidup. Anak menjadi aktif pikirannya. Keaktifan tersebut pun menghidupi daya kreasi dan kritisi anak tentang pengetahuan tertentu yang berhubungan dengan tema-tema nilai hidup di sebuah isi cerita pada dongeng.

Nilai moral. Dalam melakuakan penanaman nilai-nilai moral, orang tua mentransfer nilai moral dengan mengambil pesan moral yang ada di setiap proses mendongeng. Untuk mengajak anak memahami pesan moral di setiap dongeng, ketiga orang tua melakukan dengan cara memaparkan setiap pesan moral yang terkandung dalam dongeng kepada anak, namun yang menarik adalah orang tua seringkali memberi kesempatan kepada anak untuk memaparkan "apa" dan "bagaimana" pesan moral yang terkandung didalam dongeng yang disampaikan oleh orang tua maupun dongeng yang 
pernah dibaca oleh anak secara mandiri. Setelah itu orang tua melakukan koreksi terkait pesan moral yang disampaikan oleh anak sehingga hal ini dapat mendorong anak untuk memahami nilai-nilai moral yang terkandung di setiap dongeng. Dongeng menjadi tidak semata imajiner dan artistik tetapi dijadikan sebagai bahan dialog dengan anak. Di sini anak diajak melakukan interpretasi sederhana untuk mencerna kandungan nilai. Proses internalisasi seperti ini yang menunjukkan anak terbukti sebagai subyek moral yang aktif.

Nilai agama. Penanaman nilai-nilai agama dilakukan oleh orang tua dengan cara menyisipkan kandungan nilai di isi dongeng. Cara ini membantu memfasilitasi Lh menanamkan nilai agama secara langsung dan konkrit. Lh merasa cara demikian lebih fleksibel dan luwes, tidak langsung (indirected) sehingga ayat al-Qurán dapat disampaikan tidak letterlijk atau kaku. Melalui media dongeng Lh telah menemukan cara yang tepat untuk menjelaskan bagaimana ayat-ayat Alqur'an dan perintah-perintah Allah dikemas secara rapi untuk dapat diterima dan dipahami oleh anak lebih mudah dan masuk akal. Salah satu contoh yang dilakukan oleh Lh adalah perintah sholat. Pada dasarnya sholat itu ada di Alqurán, namun LH mengajarkannya justru ditopang dengan dongeng-dongeng. Begitupun dengan $\mathrm{Fz}$ yang memberikan gambaran secara langsung nilai dalam Alquran melalui dongeng agar anak bisa memvisualisasikan nilai yang terkandung dalam penceritaan tersebut.

Nilai sosial dan realita. Secara teknis penanaman nlai-nilai dari kehidupan nyata dan realita sosial disampaikan oleh Lh, Fz dan Az melalui penjabaran kontekstual di sekitar lingkungan hidup anak. Misalnya, ketika anak berada ditempat dan setting tertentu, di rumah atau di luar rumah, secara spontan Lh menceritakan kepada anak dongeng yang sesuai dengan kondisi tersebut. Hal ini dimaksudkan agar anak dapat merespon secara langsung tentang cerita dongeng yang disampaikan dengan setting yang telah dikondisikan Lh sehingga anak dapat belajar dari lingkungan sekitar mengenai nilai-nilai positif dengan contoh nyata yang berasal dari lingkungan sosial anak.

Skill dan kreativitas. Melalui media dongeng yang diberikan kepada anak, Lh dan Az juga dapat menanamkan ketrampilan dan kreativitas mendongeng pada anak. Pengajaran keterampilan anak untuk mendongeng yang dilakukan oleh Lh awalnya didasari atas sifat anak yang cuek, tetapi ditimbang-timbang anaknya tertarik dalam dunia dongeng. Usaha-usaha yang dilakukan oleh Lh adalah dengan cara memberikan dukungan penuh kepada anak. Seperti memberi materi dari buku. LH juga mencari cara untuk belajar memahami keterampilan mendongeng sebelum dia membelajari anaknya untuk latihan mendongeng.

\section{DISKUSI}

Dongeng merupakan suatu pilihan dalam menerapkan prinsip-prinsip positive parenting karena dongeng dibangun atas dasar prinsip hubungan kenyamanan antara orangtua dengan anak yang mana komunikasi adalah bagian penting dari adanya hubungan ini (Zolten \& Long, 2006). Selain itu, dongeng juga memiliki daya tarik tersendiri sehingga anak tidak akan protes bila diberikan dongeng, bahkan anak akan lebih sering meminta orangtua untuk menyampaikan dongeng. Dongeng mewakili jenis komunikasi dua arah dalam pengasuhan dan sangat baik mendukung penanaman nilai anak dari cara indoktrinasi, mekanistik menuju cara demokratis melalui internalisasi dialogis (Ilahi, 2013; Superka dalam Muslich, 2011). Kekayaan tersebut menjadi bagian dari adanya keterampilan positive parenting bagi orang tua yang menggunakan dongeng untuk penanaman nilai pada anak. Ketrampilan pengasuhan menggunakan dongeng ternyata dibentuk oleh motivasi orang tua sehingga mereka memiliki kesadaran baru bahwa dongeng menjadi salah satu cara yang tepat, demokratis, dan kreatif untuk menanamkan nilai pada anak (Innayah, 2011; Superka dalam Muslich, 2011).

Kemampuan modifikasi dongeng sebagai positive parenting didasari motivasi internal dan eksternal yang dibentuk oleh pengalaman masa lalu orang tua. Pengalaman tersebut menyadarkan orang tua bahwa dongeng menjadi alternatif ramah dalam menanamkan nilai pada anak. Nilai-nilai ditransformasi menjadi lebih fleksibel dan kreatif. Pada sudut pandang anak, modifikasi dongeng telah membuka ruang interaktif antara orangtua dan anak untuk melibatkan diri dalam pencapaian internalisasi nilai-nilai pada anak. Hasilnya, anak dapat memutuskan sendiri sikap dan tindakan bernilai karena pelibatan aktif-kreatif anak. Kepatuhan anak dengan demikian muncul dari proses aktif pemahaman diri bukan keterpaksaan karena instruksi terarah.

Dengan mendongeng, anak memiliki atensi (perhatian). Selain itu, daya tarik anak terhadap nilai yang disampaikan tidak lagi dibentuk melalui instruksi terarah. Cerita yang tersaji dalam dongeng 
menstimulasi anak meningkatkan perhatian dari sebuah daya tarik isi ceritanya. Anak menjadi aktif untuk terlibat secara pikiran melalui kegiatan menyimak dan tenggelam bersama ijaminasi cerita. Anak merasa tidak tertekan karena sebenarnya dia sedang menikmati dongeng. Cerita dongeng mampu merangsang pusat perhatian anak, meskipun yang mendongeng tidak harus terampil.

Anak yang penuh perhatian saat terlibat dalam aktifitas mendongeng berarti dia sebenarnya memiliki fokus terhadap alur cerita yang tersaji. Pada proses tersebut, modifikasi dilakukan dengan menyisipkan isi keagamaan, bahkan dijadikan sebagai alat untuk menghafalkan ayat-ayat Al-Quran. Keterlibatan anak dalam alur cerita dongeng telah membangkitkan perhatian dan penyertaan ayat Al-Quran menjadi mudah dikondisikan karena anak berada dalam situasi menyenangkan. Ketika pusat perhatikan berfungsi penuh, anak bisa langsung terlibat juga pada aktifitas tambahan berupa menghafal AlQuran. Penerimaan penyelia ayat Al-Quran karena orang tua memasukkan sejumlah terjemahan ayat menjadi bagian yang tidak terpisahkan dari cerita. Pelibatan cerita terjemahan dan ayat Al-Quran dapat menyimpan memori jangka panjang karena tuntutan kegiatan menyimpan informasi hafalan tidak semata-mata mengulang-ulang ayat tetapi disertai organisasi kategorisasi, imajinasi, pemanggilan kembali (Desmita, 2009) yang kesemuanya dikonstruksi dari proses modifikasi cerita.

Isi cerita dongeng yang telah dimodifikasi menjembatani antara dunia praktis dan imajinasi saling terhubung. Situasi tersebut sangat memikat anak karena proses kognitif anak memang berada dalam perkembangan pra-operasional. Dongeng kemudian meningkatkan stimulasi rasa ingin tahu anak. Berbeda dengan penyampaian monolog dan indoktrinasi (instruksi) yang subyek pengetahuan hanya di pemilik instruksi atau pendongeng. Pada proses mendongeng yang sudah dimodifikasi, anak ikut terlibat dalam dialog karena anak mampu memahami antara cerita dengan situasi yang dihadapi (Hidayah, 2009). Penerimaan cerita tersebut akhirnya memantik rasa ingin tahu anak. Selain itu, ketika sumber dongeng digali dan dikembangkan dari buku-buku dongeng, proses tersebut membangkitkan motivasi anak mempunyai minat membaca.

Mengaktifasi imajinasi anak ternyata merupakan tulang punggung metode pengasuhan positif untuk menanamkan nilai-nilai pada anak dari memposisikan anak sebagai obyek moral menjadi subyek moral. Anak mampu membangun keingintahuannya dan pro- aktif untuk memberikan umpan balik. Di sini sugesti positif untuk memberi nasihat mampu menghindari konflik, pemaksaan nilai secara hitam-putih atau menegur dengan memarahi anak. Modifikasi mampu menciptakan situasi yang nyaman daripada situasi yang tertekan, ketegangan dan konflik untuk tujuan-tujuan pemaksanaan penanaman nilai (Lihat Gambar 2).

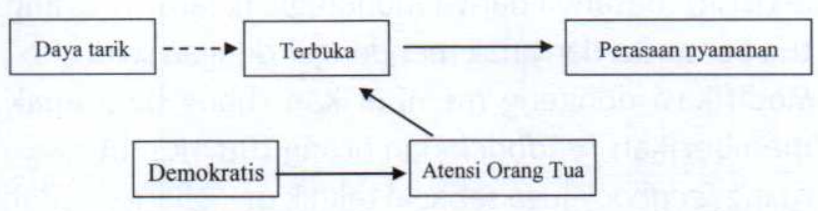

Gambar 2. Proses anak merasa nyaman dengan orangtua

Penanaman nilai dengan modifikasi dongeng berjalan sesuai dengan prinsip positive parenting. Orang tua dan anak memiliki hubungan timbal-balik (interaktif) dan terbuka. Nilai-nilai diberikan kepada anak secara fleksibel dan kreatif, tidak terkecuali nilai agama. Dalam modifikasi terjadi diskusi interaktif antara orang tua dan anak. Diskusi ini menuntut orang tua menanggapi anak yang sedang bertanya, utamanya mengenai konten dongeng. Orang tua pun memiliki kecenderungan membuka diri sedemikian rupa sehingga mampu mengubah penanaman nilai dari mekanistik menuju sikap terbuka. Relasi tersebut menjadikan perasaan nyaman, tidak taken for granted.

Modifikasi dongeng seperti proses hypnoticstory-telling. Proses hypnotic-story-telling adalah proses memasukkan sugesti-sugesti positif pada anak dalam waktu tertentu yakni ketika anak berada dalam kondisi pra-sadar dan konsentrasi penuh. Ketika anak berada dalam kondisi ini, alam bawah sadar anak sedang aktif sehingga orangtua lebih mudah untuk memasukkan nilai-nilai yang terdapat dalam dongeng. Salah satu kondisi yang tepat adalah ketika menjelang tidur atau sesaat sebelum anak benar-benar terlelap dalam tidurnya, sehingga dongeng lebih baik disampaikan secara tuntas walaupun anak sudah tertidur.

Di samping itu, dongeng dapat difungsikan sebagai sarana memberi nasihat dan sugesti secara halus dan lebih slow, sehingga lebih diterima anak. Hal ini menumbuhkan kedekatan antara subjek dengan anak sehingga anak merasa nyaman. Kedekatan terjadi setelah anak merasa tertarik ketika subjek menyampaikan dongeng. Anak merespon terbuka 
dan mereaksi secara kognitif dengan turut serta memberikan ide (kognitif), mengungkapkan perasaan (afektif), atau menceritakan pengalamannya. Rasa nyaman juga diperoleh dari umpan balik orang tua (Zolten \& Long, 2006).

Orang tua juga berusaha menghargai dan mendengarkan anak ketika anak bercerita. Ini bagian dari kemampuan orang tua memberikan perhatian pada anak. Pada dongeng konvensional artistik, biasanya hanya monologis (searah). Orang tua bercerita dan anak mendengar dengan suka cita. Modifikasi dongeng memberikan ruang bagi anak memberikan feedback dan orang tua memberikan ruang feedback juga sebagai teknik menghargai sudut pandang anak. Relasi intersubyektif memberikan daya pikat saling memanusiakan dalam proses penanaman nilai pada anak.

Dongeng menjadi alat membangun sugesti. Nilai-nilai yang tersampai akan diterima dengan konsentrasi penuh dan sesuai dengan penalaran anak. Ketika alur cerita dalam dongeng berada pada posisi klimaks atau menarik, orangtua memanfaatkan waktu untuk menanyakan kepada anak nilai mana yang sepantasnya diterima dan nilai mana yang harus dibuang. Ketika anak sedang mendengarkan dongeng, alam pikiran anak berada dalam alam pikir subkonsius. Pada tingkat ini, kondisinya sama dengan ketika mereka sedang melihat televisi. Ada sebuah kesamaan dalam tingkat alam pikir ini, yaitu semua nilai yang mereka terima akan masuk ke alam pikirannya. Oleh karena itu seringkali acara-acara dalam televisi diberhentikan sementara pada waktu klimaks dan menarik karena di sana iklan-iklan dalam televisi ingin menyampaikan sugestinya. Inilah kesempatan para orang tua untuk memasukkan nilai-nilai yang baik. Apapun nilai yang dimasukkan oleh orang tua melalui dongeng tidak akan diprotes anak, karena mereka akan larut dalam keasyikan mendengar dongeng (Nur'aini, 2010).

Modifikasi dongeng juga membantu penajaman nilai pada konten dongeng. Temuan ini yang juga membedakan lebih lanjut dari dongeng yang sematamata artistik konvensional sehingga pesan moral tidak eksplisit tersampaikan. Modifikasi dongeng menambah ruang penegasan nilai konten dongeng, bahkan menjadi bahan diskusi antara orang tua dan anak. Implikasinya bahwa teknik diskusi menjadi lebih penting agar mempunyai gambaran dan penegasan dalam mencontoh nilai dan perbuatan baik pada dongeng yang disampaikan. Diskusi membuka pikiran anak. Kegiatan ini dapat memicu anak berani berbicara dan berdialog. Anak menjadi subyek moral yang merekonstruksi pemahaman mereka dengan sudut pandangnya sendiri.

Modifikasi dongeng memberikan ruang kepada anak untuk mengemukakan apa yang ada dalam pikirannya. Anak juga diberikan kesempatan untuk berimajinasi dengan kreativitasnya secara bebas. Hal ini karena ketika anak diberikan dongeng, anak akan memvisualisasikan apa yang disampaikan. Apalagi, jika teknik mendongeng yang diterapkan disertai dengan stimulus-stimulus agar pikiran anak terbuka. Misalnya meminta anak untuk menentukan alur cerita atau karakter di dalam tokoh dengan memberikan pertanyaan kepada anak mengenai seperti apa tokoh dalam dongeng, atau menstimulasi anak untuk membuat dongeng sendiri. Di sinilah fungsi perkembangan kognitif anak terfasilitasi secara aktif dalam modifikasi dongeng sehingga dongeng telah diubah dari monolog menjadi dialog. Penanaman nilai dengan dongeng telah membebaskan anak dari indoktrinasi pasif menuju internalisasi aktif yang menempatkan anak sebagai subyek moral.

\section{KESIMPULAN}

Dongeng menjadi salah satu pengasuhan positif. Pilihan praktis tersebut didorong motivasi intrinsik dan ekstrinsik orang tua atas refleksi pengalaman masa lalunya yang dialami dalam sejarah pengasuhan yang penuh dongeng. Dongeng menjadi warisan yang mengakar secara pibadi, menginspirasi dan menumbuhkan motif-motif instrinsik para subyek. Mereka secara sadar melahirkan kembali dongeng sebagai media yang tepat dalam menanamkan nilai-nilai positif pada anak saat ini. Dari proses mendongeng, ditemukan ada rekonstruksi nilai pada proses transformasi pada anak yakni, nilai moral-agama, nilai sosial dan realitas. Nilai itu juga membangkitkan pemahaman baru pada anak karena meningkatnya ketrampilan dan kreatifitas anak untuk turut merekonstruksi nilai tersebut.

Penanaman nilai dengan modifikasi dongeng membangun hubungan yang nyaman antara orangtua dengan anak. Perkembangan kognitif anak terstimulasi dengan baik karena anak terstimulasi melalui respon interaktif saat mendongeng. Stimulasi perkembangan kognitif maksimal karena prinsip pengasuhan positif berjalan dengan baik dalam ruang dialogis, tidak menkan, lebih demokratis, mengakui hak anak, meningkatkan daya tarik anak pada umpan balik dari dongeng yang diberikan, dan memberikan simulasi dini penerapan nilai dari hasil refleksi anak atas dongeng-dongeng yang diberikan. 
Hasil penelitian ini memberikan pelajaran bagi orang tua bahwa penerapan nilai yang mekanistik, monologis (searah), dan biasanya penuh instruksi melahirkan beberapa respon perilaku konflik antara orang tua dan anak atau perlawanan dari anak karena anak terpojok dan tidak nyaman. Peristiwa ini terjadi karena nilai disodorkan dalam budaya dialog yang masih mengalami kesenjangan baik kognitif dan perilaku. Modifikasi dongeng

\section{DAFTAR PUSTAKA}

Ahyani, L. N. (2010). Metode Dongeng Dalam Meningkatkan Perkembangan Kecerdasan Moral Anak Usia Prasekolah. Jurnal Psikologi Universitas Muria Kudus, 1(No.1), 24-32.

Biechonski. (2004). The Use Fairy tales In Adut Psychoterapy and Hypnoterapy. Sach.

Desmita. (2009). Psikologi Perkembangan. Bandung: PT Remaja Rosdakarya

Hedo \& Sudhana, D. J. (2014). Perbedaan Agresivitas pada Anak Usia Dini yang Dibacakan Dongeng Dengan yang Tidak Dibacakan Dongeng Sebelum Tidur Oleh Ibu. Jurnal Psikologi Udayana , 213-216.

Hidayah, R. (2009). Psikologi Pengasuhan Anak. Malang: UIN Malang Press.

Ilahi, M. T. (2013). Quantum Parenting. Yogyakarta: Ar Ruzz Media.

Innayah. (2011). Metode Penanaman Nilai AkhlakAnak Pada Keluarga Tki (Tenaga Kerja Indonesia) Di Desa Pucakwangi Kecamatan Pageruyung Kabupaten Kendal Tahun 2011. Salatiga: STAIN Salatiga.

Kartono, K. (2007). Psikologi Anak. Bandung: Mandar Maju.

Lestari, S., \& Asyanti, S. (2008). Strategi penanaman nilai dan penanganan konflik nilai dalam praktek pengasuhan anak pada keluarga Jawa (Laporan penelitian fundamental tahun pertama). Surakarta: Fakultas Psikologi Universitas Muhammadiyah Surakarta. Retrieved from https://publikasiilmiah.ums.ac.id/bitstream/ handle/11617/2692/2008_fr_sri_lestari_depan. pdf?sequence $=8 \mathrm{E}$ is Allowed $=y$

Lyons, Evanthia \& Coyle, Adrian. (2007). Analyzing Qualitative Data in Psychology. Singapore: Sage Publication

Mahmud, A. (2015). Penerapan Pembelajaran Melalui Pendidikan Moral Guna Meningkatkan ditemukan bahwa situasi kontradiksi nilai dapat dijembatani karena mendongeng telah membuka penalaran anak terhadap nilai yang disampaikan. Logika anak dipahami dan mendapatkan ruang, bahkan diapresiasi. Penanaman nilai menjadi lebih fleksibel, kreatif, dan menyenangkan. Orang tua dapat meningkatkan perhatian anak dalam situasi dialogis. Anak menjadi subyek moral penuh daripada obyek moral.

Kepribadian dan Sikap Siswa. FKIP UNTAD.

Maulida. (2015). Penanaman Nilai-Nilai Moral Pada Anak Usia Dini Melalui Pengenalan Konsep "Local Wisdom" Sederhana Mulai Dari Keluarga. Prosiding Seminar Nasional Pendidikan "Inovasi Pembelajaran Untuk Pendidikan Berkemajuan". Ponorogo: FKIP Universitas Muhammadiyah.

Muhtadi. (2007). Teknik dan Pendekatan Penanaman Nilai Dalam Proses Pembelajaran di Sekolah. Majalah Ilmiah Pembelajaran, 3(1), 60-69.

Muslich, M. (2011). Pendidikan Karakter. Jakarta: Bumi Aksara.

Nur'aini, F. (2010). Membentuk Karakter Anak Dengan Dongeng. Surakarta: Indiparent.

Orde, H. V. (2013). Children Need Fairy Tales. Information, pp. 17-18.

Raharjo, S. (2002, November 19). Penanaman nilai-nilai agama Islam pada anak usia dini di kelompok bermain 'Aisyiyah Al-Husna II Pengasih, Kec. Pengasuh, Kab. Kulon Progo. Fakultas Ilmu Pendidikan Universitas Negeri Yogyakarta, Yogyakarta. Retrieved from http://eprints.uny.ac.id/27198/1/Setiaji\%20 Raharjo.pdf

Sari, A. (2010). Pengasuhan dan penanaman nilai terhadap anak usia dini (telaah komunikasi keluarga; suatu studi deskriptif. Jurnal Makna, 1(1), 1-12.

Siswanto, E. (2014). Pengasuhan orang tua dalam pembelajaran nilai moral pada anak usia dini keluarga TKW dalam peer group bermain di Dusun Ngepeh, Desa Sukorejo, Kecamatan Kebonsari, Kabupaten Madiun. Nugroho Jurnal Ilmiah Pendidikan, 2(2), 167-173.

Smogorzewska, J. (2012 ). Storyline and Associations Pyramid as Methods of Creativity Enhancement: Comparison of Effectiveness in 5-year-old 
Children. Thinking Skills and Creativity, 7, 28-37.

Taylor, M. (2012, February 22). 8 reasons why fairy tales are essential to childhood. Retrieved
02 11, 2016, from http://imaginationsoup. net/2012/02/22/fairy-tales-are-essentialto-childhood/

Zolter, Kristin \& Long, Nicholas. (2006). Parent/ Child Communication. Center For Effective Parenting. University of Arkansas. 